\title{
Exploring Language Attitudes of Undergraduate English Language Learners Towards Sindhi (L1) and English (L2)
}

\author{
Nishfa Rajper \\ MS Scholar, Mehran University of Engineering \& Technology, Jamshoro \\ Shabana Gul Tunio \\ Assistant Professor, Sindh Agriculture University, Tandojam \\ Syed Waqar Ali Shah \\ Lecturer, Mehran University of Engineering \& Technology, Jamshoro \\ Iram Panhwar and Iqra Majeed \\ MS Scholars, Mehran University of Engineering \& Technology, Jamshoro
}

\begin{abstract}
The aim of this paper was to investigate the language attitudes of undergraduate English language learners (ELLs) towards Sindhi (their mother tongue) and English language which were affected through dominant discourse of language policy. The participants for the current study were selected from the Institute of English language and Literature, University of Sindh, Jamshoro. The study used semi structured interviews in order to collect the indepth data about language attitudes of students towards Sindhi and English language. The researcher used purposive sampling, total number of the participants considered in the study were $(n=10)$. Thematic analysis was used for analysisng the data of the study. The findings of the study revealed that undergraduate English language learners (ELLs) have more positive attitudes towards English language than Sindhi language (their mother tongue). The participants perceived that their personalities are grooming. They are being encouraged and considered educated when they speak English language. On the other hand talking about language attitudes towards Sindhi language participants shared that they don't feel any change in their personalities. They are discouraged to speak Sindhi language and considered as less hard working and less intelligent when they speak Sindhi language.
\end{abstract}

Keywords: Language attitude, English language learners, Sindhi, English, language policy.

DOI: $10.7176 /$ JLLL/84-02

Publication date: December $31^{\text {st }} 2021$

\section{Introduction}

Language is the crucial aspect of ethnic identity. It is considered as important foundation for ethnic identity. The identification of native tongue is solidly recognized through various ethnic groups and it is frequently used as the fundamental symbol of dissimilar ethnic groups (Mei, 2006). Almost 7000 different languages are spoken around the globe and most of these languages face risk of extension and will abandon by the end of twenty-first century (Crystal, 2000). There are many economic and sociopolitical factors which will lead to the extinction of nearly half of languages of the world

One of the crucial factor which will play most important role in extinction of languages is the language attitude of speakers towards their own native languages. According to Eagly and Chaiken, attitude is a psychological tendency which can be expressed by evaluating a specific entity with certain degree of favour or disfavour, wherein evaluative aspect is the central aspect of an attitude (Eagly \& Chaiken, 1993, p.1). Suge said that, sustainability of a language is mostly determined by the language attitudes of its speakers, and language maintenance will occur if the speakers of language have a positive attitude to towards their language, but if the speakers of the language will have negative attitudes towards a language, there is possibility that the speakers of the language do not desire to maintain their language (Suge, 1967). As Abbas says that if the speakers will have negative attitude towards their language, the future of their language is jeopardized (Abbas \& Iqbal, 2018). Moreover attitude is the result of language policy, as Crawford and Pablo concluded that language attitudes of speakers and also speakers of other languages are affected through the status of the language in specific society or language policy (Crawford \& Pablo, 2016).

Pakistan is a multilingual country with almost 74 languages spoken in the country (Siddiqui, 2019). According to the Ethnologue, we get sum of 66 languages when we exclude dialects of the same languages listed individually (Ethnologue, 2016). The major languages of Pakistan, according to census are, Punjabi 44.15\%, Pashto $15.42 \%$, Sindhi 14.10\%, Siraiki 10.53\%, Urdu 7.57\%, Balochi 3.57\%, and Others 4.66\%. English is considered as official and international language of the country. It remains most active language in all powerful domains as a legacy of colonizers. English is exclusively use for the purpose of judiciary, administration even after the seventy years of decolonization (Ansari \& Mangool, 2015). English is spoken exclusively by influential 
population of the country. It is regarded as symbol of status and the institutes which are teaching English are marked as obligatory in the state. English is recognized as passport to successful future (Umrani \& Bughio, 2017). As a result speakers language attitudes towards their mother tongue and English language may be affected, as Suek says that the dominance of official language over a group of languages affect students attitudes toward their mother tongue (Sindhi) and English language (Suek, 2014).

Sindhi is an Indo Aryan regional language, used by Sindhis of Pakistan. According to Bughio 68 languages are used in Sindh. Sindhi is the most widely spoken language with $52.4 \%$ percent of the population speaking it (Bughio, 2001, p.30). According to Rahman, Sindhi language had such a strong position in pre-partition era. Sindhi was studied as a subject in academic institutions across different levels. It was used as a teaching tool throughout colleges and was also implemented at universities. Sindhi has also been used at the lowest levels of government, the courts, and media (Rahman, 1998). But after partition the status of Sindhi language has been changed. Sindhi language is not teach even at primary level in private schools. As Pathan (2018) mentioned that in academic institutions English and Urdu are the dominant languages. Sindhi language is no longer teach in private schools even at primary level. Sindhi is now at a disadvantage as a result of ineffective language policies (Pathan, 2018).

\subsection{Problem Statement}

Indigenous languages are the pillars of any state. They serve to the diversity of culture and linguistics (David, 2001). Pakistan is a multilingual country with almost 74 languages spoken in it (Siddiqui, 2019). More importance is given to the national and international languages and less focus is given to indigenous languages which are different in every province (Ali, 2015). Hence language policy has affected the language attitudes of undergraduate English language learners (ELLs) towards their mother tongue (Sindhi) and English language. As Suek (2014), stated that the dominance of official language over a group of languages affect student's language attitudes toward their mother tongue and English language (Suek, 2014).

\subsection{Research Question}

The current study is entirely based on the research question given below: Q1. What are the language attitudes of undergraduate English language learners (ELLs) towards their mother tongue Sindhi and English language?

\section{Literature Review}

The term attitude is basically used in social psychology and that is considered the primary area of attitude research. Attitude research has played very important and fundamental role in the field of psychology for long time but it has become also the main area of interest in the field of sociolinguistics (Garrett et al., 2003). According to Eagly and Chaiken, attitude is a psychological tendency which can be expressed by evaluating a specific entity with certain degree of favour or disfavour; wherein evaluative aspect is the central aspect of an attitude (Eagly \& Chaiken, 1993, p.1). Evaluative response is the core component of three aspects of attitude, namely cognitive, affective, and behavioural attitudes.

Akram and Yasmeen conducted study on language attitudes towards Punjabi and English language learning. The study used the questionnaire for data collection and the data was analysed statistically. The research concluded that Pakistan is linguistically diverse country having a situation of diglossia in which two or more different languages are used in the same society. But these languages have different prestige, status and function. Some of the languages are highly prestigious $(\mathrm{H})$ and other language are less prestigious $(\mathrm{L})$. English is considered as high prestigious language and Punjabi is considered as local indigenous language. The findings of the study presented that the people of Faisalabad have less positive attitudes towards Punjabi language and more positive attitudes towards English language since the structure, status, function and prestige of these languages are different (Akram \& Yasmeen, 2011).

Soomro (2016) conducted the study on attitudes of undergraduates towards learning and speaking English language by using mixed methodology. Questionnaire and semi structured interviews ware used in order to collect the data of the study. The findings revealed that participants have more positive attitudes towards learning and speaking English language and most of them perceived that use of English language do not threat their mother tongue (Soomro, 2016).

Dewi and Sediadi (2018) conducted study on language attitudes and factors that determine language choices of English department students. Quantitative methodology was used in the study in order to investigate the language choice and factors which determine the language choices. The researchers collected the data through questionnaire which was constructed to investigate student's language attitudes, language choice and motivation for studying English. The results presented that students of English department of Bina Nusantara University have more positive attitudes towards English language. The majority of students stated that English is international language and it provides more career opportunities (Dewi \& Sediadi, 2018)

Abbas and Iqbal (2018) conducted study on the language attitudes of Pakistani youth towards Punjabi, Urdu 
and English language. The researchers used quantitative research methodology in order to critically analyse the language attitudes of young participants towards Punjabi, Urdu and English language. More specifically questionnaire was used by the investigators for collecting the data of current study. The study used large sample of $(n=445)$ participants for investigating the issue of language attitudes of youth towards Punjabi, Urdu and English language. The data was analysed through descriptive statistics. The result shows that participants connect sense of superiority with English language and they have integrative motivation for Punjabi and Urdu language while they contain the instrumental motivation for English language. The research appeals that language policy in education should be change so that all languages should have environment where they can get balanced developments and speakers may have positive attitudes towards their indigenous languages (Abbas \& Iqbal, 2018).

Rahman \& Shahabullah researched on language attitudes of Pashto speakers towards Pashto language. The researchers collected the data from undergraduate students; questionnaire was used in order to collect the data of the study. The findings of study revealed that ungraduated students have more positive attitudes towards English language. They were of the perspective that through English language we can explore the world since all resources are available in English language (Rahman \& Shahabullah, 2020).

\section{Research Methodology}

The current study used qualitative research methodology in order to get in-depth understanding of the language attitudes of undergraduate English language learners (ELLs) towards Sindhi and English language. Qualitative methodology is a descriptive phenomenon which consider people's interpretation, opinions, observed behaviours, and beliefs and it takes the live talks from individual regarding any problem (Mohajan, 2018). According to Collis and Hussey (2003) qualitative methodology often used to get rich data. It usually takes small samples for data collection, human interpretation are considered as major source for data generation. The researcher used semistructured interviews for collecting the data of the study. According to, Allison et al, semi structured is used to obtain the information about the interviewee's interpretations, meanings, value and experiences and their surrounding environment (Allison et al. 1996). Semi structured interviews mainly involve predetermined open ended questions asked by participants to get in-depth yet focused responses (Corbin \& Strauss, 2014).

\subsection{Sampling \& Participants}

Complete number of the participants used in the current study were $(n=10)$. The participants are currently enrolled in BS part I and part II linguistics at Institute of English Language and Literature University of Sindh, Jamshoro. The participants were selected through purposive sampling. Purposive sampling is a method in which the specific settings, people, or situations are largely characterised in order to get the crucial data that cannot be obtained from other possibilities (Maxwell, 1996).

\section{Data Collection \& Analysis}

Thematic analysis was used in the current study in order to analyse the data critically. Thematic analysis is the systematic process of identifying, organizing, and offering insight into patterns of meaning (themes) across a dataset. Thematic analysis permits the researcher to perceive and make sense of shared experiences and knowledge (Braun \& Clarke, 2012).

\section{Findings \& Discussion}

Findings of the present study has revealed that language policy has affected the language attitudes of undergraduate English language learners (ELLs). The participants have showed both types of positive and negative attitudes towards Sindhi language and they have showed only positive attitudes towards English language. The themes related to positive and negative language attitudes of undergraduate English language learners (ELLs) towards Sindhi and English language are discussed as under:

\section{Positive Attitudes towards Sindhi language}

I. Affiliation with mother tongue

The theme through which the positive attitudes of the participants towards their mother tongue (Sindhi) were reflected is named as "affiliation with mother tongue". The participants shared that Sindhi is their mother tongue. They feel happy and proud when they speak their mother tongue (Sindhi). One of the participant narrated that: Sindhi is my mother tongue. I feel proud of myself when I speak my mother tongue $(P-10)$.

\section{Negative Attitudes towards Sindhi language}

\section{Ungroom personality through Sindhi language}

Negative attitudes towards Sindhi language was a recurring theme in the data which was explored by researcher by conducting responses of the learners about how they feel when speak Sindhi language. Out of 10 participants 7 participants shared that speaking Sindhi language does not help them in grooming their personalities. They shared that they don't feel any change in their personalities when they speak Sindhi language. Moreover they said that they feel nothing new while communicating in Sindhi language in their surroundings with their fellow 
beings .One of them stated that:

I don't feel change in my personality when I speak Sindhi language. It's normal for me as it is my own mother tongue (P-3).

II. People's psyche affecting language attitudes

Another emerged theme of negative attitudes of learners towards their mother tongue (Sindhi) is the people's psyche which is directly or indirectly responsible for negative attitude of learners towards mother tongue (Sindhi). Out of 10 participants 9 shared that they are discouraged by the people that being English language learners they are not using English language may be they are not sincere with their study or they are not intellectual to use English language. This discouragement has resulted into the negative language attitudes of undergraduate English language learners (ELLs) towards their mother tongue. This psyche of people has compelled to switch their mother tongue. They mostly prefer to use English language in order to avoid such type of discouragement. One of the participant shared that:

When I speak only Sindhi then people say that she is uneducated and knows nothing. There is no value of Sindhi language. I should not speak Sindhi language because in today's world there is value and need of English language and people are focusing only on English language and because of that I also prefer to use English in most of the domains $(P-10)$.

\section{Positive attitudes towards English language}

I. Grooming of personality through English language

The current theme talks about the positive language attitudes of the participants towards English language. The positive attitudes of the participants towards English language were analysed through their discussion about how they feel when they speak English language. The participants mentioned that they feel change in their personalities when they speak English language. They shared that they feel their personalities are grooming when they speak English language since English is the official language of the country. Same has stated by Shamim, she said that role of English in Pakistan is at peak, English is considered as instrument for achieving modernization (Shamim, 2008). One of the participant stated that:

I feel great change in my personality when I speak English language because nowadays English has more value and when I speak English language I feel like I can move with modern world (P-6).

II. People's psyche influencing language attitudes

The second theme to present more positive attitudes of undergraduate English language learners (ELLs) towards English language is people's psyche which is directly or indirectly resulting the positive attitude of learners towards English language. The positive attitudes of the participants towards English language were analysed through their discussion about different types of comments they get when they speak English language. The participants shared that they are encouraged by their parents, teachers and friends when they speak English language. They shared that their parents feel proud that their children are speaking English language. They added that their teachers and friends consider them intelligent and hardworking and give them more value when they speak English language. The participants expressed that they feel happy when they get such type of value and encouragement and in order to get this type of encouragement and value they prefer to use English language. One of the participant expressed that:

When I speak English at home, my parents feel happy and they appreciate me to use English language. My teachers give me more value and ask me to participate in classroom since thev believe I am active and intelligent student of the classroom and this is because of using English language. And when I use Sindhi language I do not get same value so I prefer to use English language (P-3).

\section{Conclusion}

The current study was based on the findings of language attitudes of undergraduate English language learners (ELLs) towards Sindhi (their mother tongue) and English language which were affected through dominant discourse of language policy. Qualitative methodology following semi structured interviews were used in order to collect the data for the study. The findings of the study revealed that undergraduate English language learners (ELLs) have more positive attitudes towards English language than Sindhi language. The participants while expressing their feelings about English language, said that English is helping them in grooming their personalities. Moreover, they also said that when they speak English language their parents, friends and even teachers consider them as educated, intelligent and hardworking. On the other hand, when they were asked about attitude towards Sindhi language, the feeling and excitement wasn't the same. The participants seemed demotivated to use Sindhi language because of the exposure and importance given to one dominant language (English). Hence it can be suggested that there is a dire need of change in such language policy. The research demands that state language policy should be change and Sindhi language should be given the status as it had in pre partition era where it was taught and learned at all educational levels. So, the participants can value their mother tongue and may keep positive attitudes towards it. 


\section{References}

1. Abbas, F., \& Iqbal, Z. (2018). Language Attitude of the Pakistani Youth towards English, Urdu and Punjabi: A Comparative Study. Pakistan Journal of Distance and Online Learning, 4(1), 199-214.

2. Akram, A., \& Yasmeen, R. (2011). Attitudes towards English \& Punjabi language learning in Faisalabad. Journal of Academic and Applied Studies, 1(4), 9-32.

3. Ali, S.S. (2015). Minority Language Speakers' Journey from the Mother tongue to the other tongue: A case study. Kashmir Journal of language Research, 18(3), 65-81.

4. Ansari, S. A., Mehmood, A., \&Mangool, R. A. (2015). Good Governance in Pakistan through Effective Laws: A Case Study of Legislative Drafting and Law Reform Processes in Pakistan. IJLDLR, 3, 11.

5. Braun, V., \& Clarke, V. (2012). Thematic analysis.

6. Bughio, Q. (2001). A Comparative Sociolinguistic Study of Rural and Urban Sindhi. Lincom Publishers.

7. Collis, J. and Hussey, R. (2003), Business Research: A Practical Guide for Undergraduate and Postgraduate Students, Palgrave Macmillan, Houndmills, Basingstoke, Hampshire.

8. Corbin, J., \& Strauss, A. (2014). Basics of qualitative research: Techniques and procedures for developing grounded theory. Sage publications.

9. Crawford, T., Pablo, I. M., \& Lengeling, M. M. (2016). Struggling authorial identity of second language university academic writers in Mexico. Profile: Issues in Teachers' Professional Development 18(1), 115-127

10. Crystal, D. (2000). Language Death. Cambridge: Cambridge University Press.

11. David, M. K. (2001). The Sindhis of Malaysia: A sociolinguistic study. Asean Academic Persalt.

12. Dewi, U. P., \& Setiadi, C. J. (2018). Language attitude and language choice in bilingual academic learning environment. Lingua Cultura, 12(4), 369-373.

13. Eagly, A. H., \& Chaiken, S. (1993). The psychology of attitudes. Belmont, CA: Thomson. Edwards, J. (2009). Language and identity: An introduction. Cambridge: Cambridge University Press.

14. Ethnologue. (2016). Languages of the World. Retrieved from https://www.ethnologue.com/statistics/country

15. Garrett, P. (2010). Attitudes to Language (1st Ed.). New York: Cambridge University press, New York.

16. Maxwell, J. A. (1996). Qualitative Research Design: An Interpretive Approach.

Thousand Oaks, CA: Sage.

17. Mei, G. (2006). Language and Ethnic Identity. Manchu Studies, (4), 47-51

18. Mohajan, H. K. (2018). Qualitative research methodology in social sciences and related subjects. Journal of Economic Development, Environment and People, 7(1), 23-48

19. Pathan, H., Shah, S. W. A., Lohar, S. A., Khoso, A. R., \& Memon, S. (2018). Language Policy and Its Consequences on Sindhi Language Teaching in Sindh, Pakistan. International Journal of English Linguistics, 8(5).

20. Rahman, T. (1998). Language and politics in Pakistan. Karachi, Pakistan: Oxford University Press.

21. Siddiqui, A.S. (2019). When a language dies. The News. Retrieved from https://www.thenews.com.pk/print/423539-when-a-language-dies

22. Soomro, N. H. (2016). Towards an understanding of Pakistani undergraduates' current attitudes towards learning and speaking English (Unpublished doctoral dissertation). University of Glasgow, Scotland.

23. Ali, S. S., \& Rahman, G. (2020). Language Attitude of Pashto Speakers towards English. sjesr, 3(3), 192-197.

24. Suek, L. A. (2014). The influence of language use and language attitude on the maintenance of community languages spoken by migrant students. Englisia: Journal of Language, Education, and Humanities, 1(2).

25. Umrani, T., \&Bughio, F. A. (2017).Language politics and role of English in Pakistan. ARIEL-An International Research Journal of English Language and Literature, 26, 114-124 